\title{
Extraction, Isolation and Identification of Useful Phyto Constituents from Dichloromethane Leave Extract of Abutilon Pannosum and Grewia Tenax Using Q-TOF LC/MS
}

\author{
Mital K. Aadesariya ${ }^{1}$, Vijay R. Ram ${ }^{1}$, Pragnesh N. Dave ${ }^{1, *}$ \\ Department of Chemistry, KSKV Kachchh University, Bhuj, Kachchh- 370001 \\ *Department of Chemistry, Sardar Patel University, Vallabh Vidyanagar-388 120 (Gujarat), India \\ *Corresponding Author: Pragnesh N. Dave, Department of Chemistry, Sardar Patel University, Vallabh \\ Vidyanagar-388 120 (Gujarat), India
}

\begin{abstract}
Plant extracts usually occur as a combination of various types of bioactive compounds or phytochemicals with different polarities. The present study investigates the qualitative and quantitative analysis of the major bioactive constituents of medicinally important plant Abutilon pannosum (A.P) and Grewia tenax (G.T) in its dichloromethane (DCM) extract of leaves by use of Liquid Chromatography Quadrupole Time of Fight Mass Spectrometry (Q-TOF LC/MS). Soxhlet extraction of sample was undertaken by continuous hot percolation method using DCM as a solvent. After extraction it was concentrated by use of distillation method. Crude DCM extracts were inserted in Quadrupole-time-offlight $(Q-T O F) L C / M S$ instrument for isolation and identification of valuable phytochemicals. The result of phytochemical investigates exhibited that there are very significant phytochemicals found in DCM extracts of A. pannosum leaves like alkaloids, sterol lipids, glycerophospholipids, fatty acid, steroid glycoside, antioxidant, and heterocyclics compounds and G. tenax leaves have alkaloids, sterol lipids, glycerophospholipids, fatty ester, fatty acid, glycoside, carotene, steroidal alkaloid, triterpene glycosides, glycerophosphates, sesquiterpenes, phosphatidylglycerol, antioxidant, antibacterial, antifungal, antiviralactivity and other biological function. Thus, DCM extract of G. tenax leaves gives decent medicinal activity compared to the DCM extract of A. pannosum leaves part. In this study, the G. tenax DCM extract have greatest number of bioactive compounds. This paper mainly deals with the extraction of active compounds from the leaves part of two plants by used of DCM solvent and investigation of the phytochemicals in DCM extract by used of $Q-T O F$ LC/MS.
\end{abstract}

Keywords: Abutilon pannosum, Grewia tenax, Dichloromethane (DCM) extract, Q-TOF LC/MS, Phytochemicals

\section{INTRODUCTION}

Plants are natural reservoir of medicinal agents. These are almost free from the side effects. ${ }^{[1]}$.Thus, since ancient times, people have been discovering the nature particularly plants in search of new drugs. This has resulted in the use of huge number of medicinal plants with curative properties to treat various diseases. ${ }^{[2]}$ Approximately $80 \%$ of the world's population trusts on traditional medicines for primary health care, most of which contain the use of plant extracts. ${ }^{[3]}$ Phytochemical constituents are the basic source for the establishment of several pharmaceutical industries. The ingredients present in the plant play a significant role in the identification of crude drugs. ${ }^{[4]}$

Khapat is the native name of (Abutilon pannosum) is one of the valuable medicinal plant burn of Malvaceae family are reported here for the first time as a part of our studies to locate new oilseed resources A pannosum is a tomentose undershrub widely distributed in India, North Africa, S W Asia and Australia, and bears spherical fruits having about 25 carpels, each of which covers hairy plant widely distributed from tropical Africa to Australia through Asia. It grows to a height of $2 \mathrm{~m}$ and bears small, ovoid fruits which contain tasteless seeds. ${ }^{[5]}$ It leaves have good medicinal activity for example antibacterial, antioxidant, antifungal etc. ${ }^{[6]}$

Guddaim is the native name of (Grewia tenax) is one of the valuable plant species in kachchh. It is basically spread in arid area such as sand and near mountains. ${ }^{[7]}$ Grewia tenax is a tree spread in 
Africa and Southeast Asiatic continents. It belongs to the Tileacea family. In fact, Grewia tenax is a plant that has been used in popular medicine in various ways in different countries. Roots are used to treat jaundice, pulmonary infections and asthma. Leaves are used against trachoma. Decoction and fruit juice are used for their tonic and anti-anemic properties. Fruits are small berries, round, orange sweetened and it may be consumed either fresh or dried. ${ }^{[8]}$ There is commercial potential in using the fruits in beverages, ice cream, yogurt, and baby food. ${ }^{[9]}$

Quadrupole-time-of-flight (TOF) mass spectrometers have rapidly been incorporated by the analytical community as powerful and robust instruments with unique capabilities. ${ }^{10]}$ In particular, they combine the high performance of time of-flight analysis in both the mass spectrometry (MS) and tandem MS (MS/MS) modes, with the well accepted and widely used techniques of electrospray ionization (ESI) and atmospheric pressure chemical ionization (APCI). ${ }^{[11]}$

The objectives of this study are to evaluate and study the potential bioactive compound of both plant leaves by used of Q-TOF LC/MS which can be considered an important for human health and the knowledge the nutritional value of both plant leaves and to take advantage of them in various nutritional applications.

\section{MATERIALS AND Method}

Abutilon pannosum and Grewia tenax leaves powder, dichloromethane, RBF (round bottom flask), condenser, heating mantle, measuring flask and thimble.

\subsection{Preparation of Extracts}

15 gm of leaves powder was extracted with 2-3 litre of dichloromethane $\left(39.6^{\circ} \mathrm{c}\right)$ for 12 hour using soxhlet apparatus by continuous hot percolation method. After extraction, it was filtered and the exclusion of solvent was done under pressure by distillation process to afforded extract. Extract were collected in air tight glass tube.

\subsection{Procedure}

The prepared extract dissolve in $0.9 \mathrm{ml}$ methanol and $0.1 \mathrm{ml} 0.1 \%$ formic acid in glass tubes, for recognition of the investigated compounds was achieved using a quadrupole coupled to time-of-flight analyzer (Q-TOF-MS 6540, Agilent Technologies, UHD). The mass spectrometry was equipped with an ESI Jet Stream source; identification and determination of the investigated drug was carried out in the SCAN mode.

\subsection{LC-Q-TOF-MS Method}

The separation of the analysts was carried out using an Agilent LC-Q-TOF-MS 6540, UHD.

\subsubsection{LC-Parameter}

The injected sample volume was $10 \mu \mathrm{L}$; Mobile phases A and B were water and acetonitrile with $0.1 \%$ formic acid, respectively. The flow rate was $0.6 \mathrm{~mL} / \mathrm{min}$. A 16 min run time was used after each analysis. The optimized chromatographic method held the initial mobile phase composition (10\% B) constant for 0 min, followed by a linear gradient to $100 \%$ B after 14 min. and return back (10\% B) at 14 min. the system featured a binary pump and vacuum degasser, well-plate auto sampler with a sixport micro-switching valve, a thermo stated column compartment. Samples were loaded onto a Reprosil C18 column $(2.0 \mathrm{~mm} \times 150 \mathrm{~mm}, 2.5 \mu \mathrm{m}$ - Dr Maisch, Germany) for metabolite separation.

\subsubsection{Q-TOF Parameter}

The LC system was connected to an Agilent 6450 ultrahigh definition quadrupole time-of-flight mass spectrometer equipped with dual electro spray Jet Stream Technology operating in positive ion mode. The operating parameters were as follows: capillary voltage: $4000 \mathrm{~V}$; nebulizer pressure: $45 \mathrm{psi}(\mathrm{N} 2)$; drying gas: $8 \mathrm{~L} / \mathrm{min}$; gas temperature: $325^{\circ} \mathrm{C}$; nozzle voltage: $1000 \mathrm{~V}$; fragment or voltage: $150 \mathrm{~V}$; skimmer voltage: $65 \mathrm{~V}, \mathrm{~m} / \mathrm{z} ; 100$ to 1700 , sheath gas temp350 ${ }^{\circ} \mathrm{C}$ and sheath gas flow $11 \mathrm{~L} \mathrm{~min}-1$. The data recorded was processed with Agilent Mass Hunter software. Accurate mass measurements of each peak from the total ion chromatograms were obtained by means of an automated calibrant delivery system using a low flow of a calibrating solution (Calibrant solution A, Agilent Technologies, Santa Clara, CA, USA). 


\section{RESULTS}

The compounds present in the DCM extract of leaves of A. pannosum and G. tenax were identified by LC-MS-Q-TOF analysis. The LC-MS-Q-TOF chromatogram (Figure 1) showed 10 peaks in $A$. pannosum and 34 peak in G. tenax indicating the presence of 10 and 34 phytochemical constituents. It is characterized and identified, which are listed with their retention time (RT), molecular formula, molecular weight (MW) and concentration (\%) in Table $1 \& 2$. The major phytochemical constituents and their biological activities obtained through the LC-MS-Q-TOF study of A. pannosum and $G$. tenax are listed in Table $1 \& 2$ respectively.

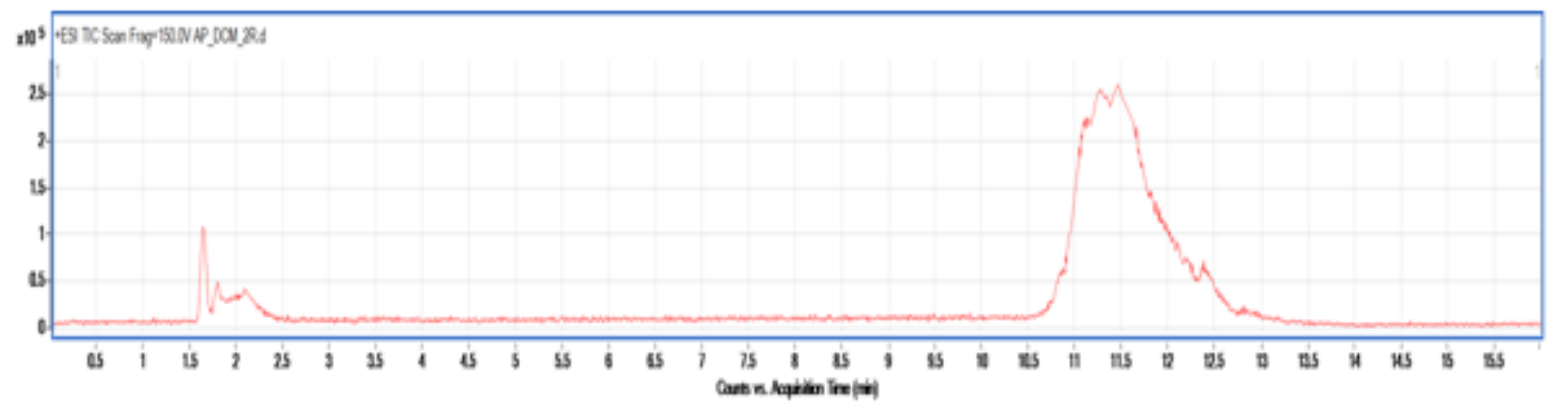

Figure1. Chromatogram of A. pannosum DCM extract

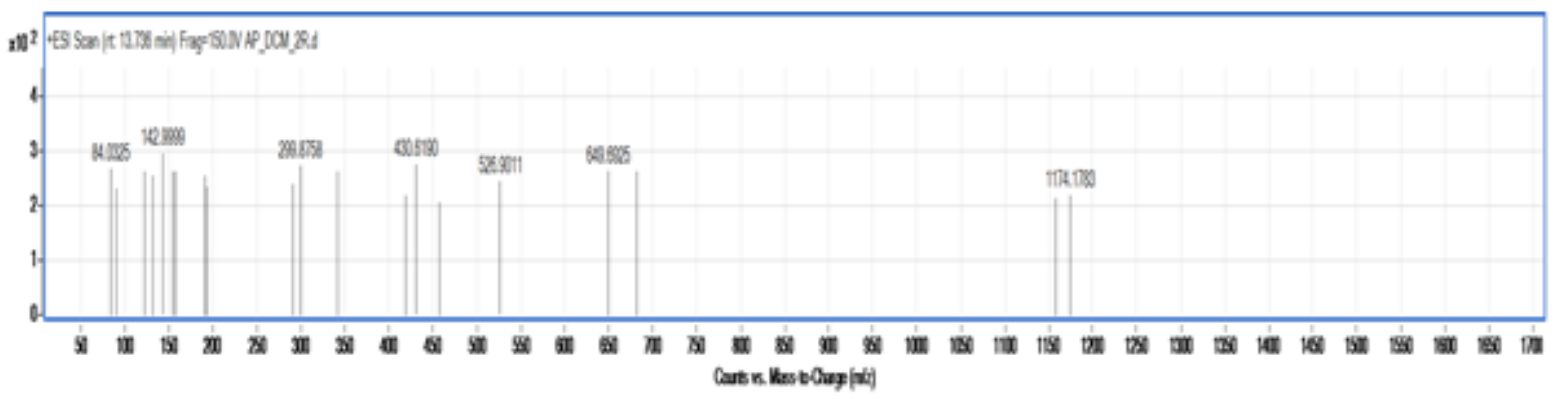

Figure2. Mass spectrum of A. pannosum DCM extract

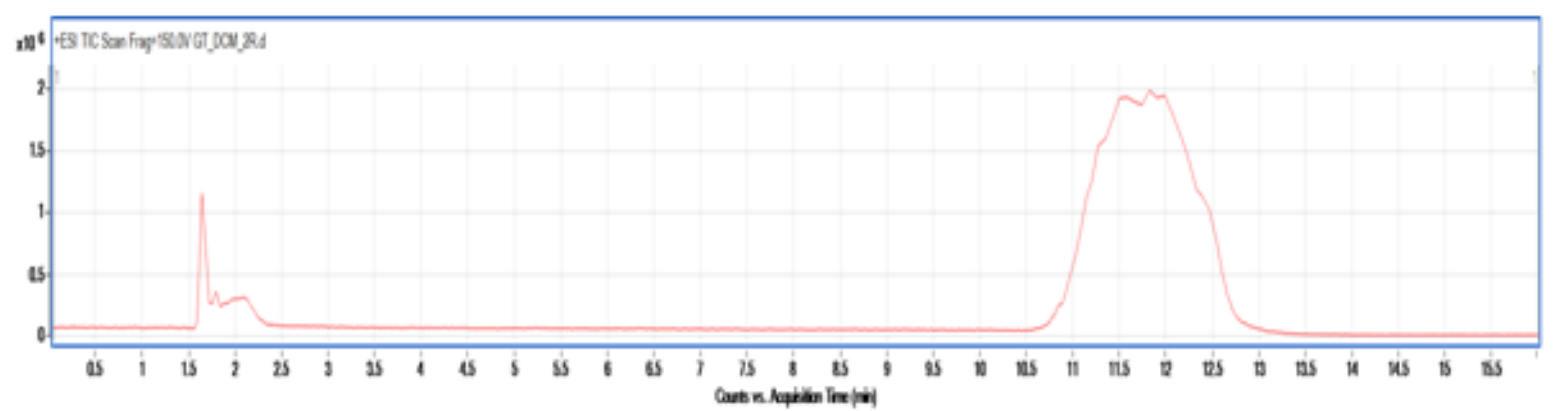

Figure3. Chromatogram of G. tenax DCM extract

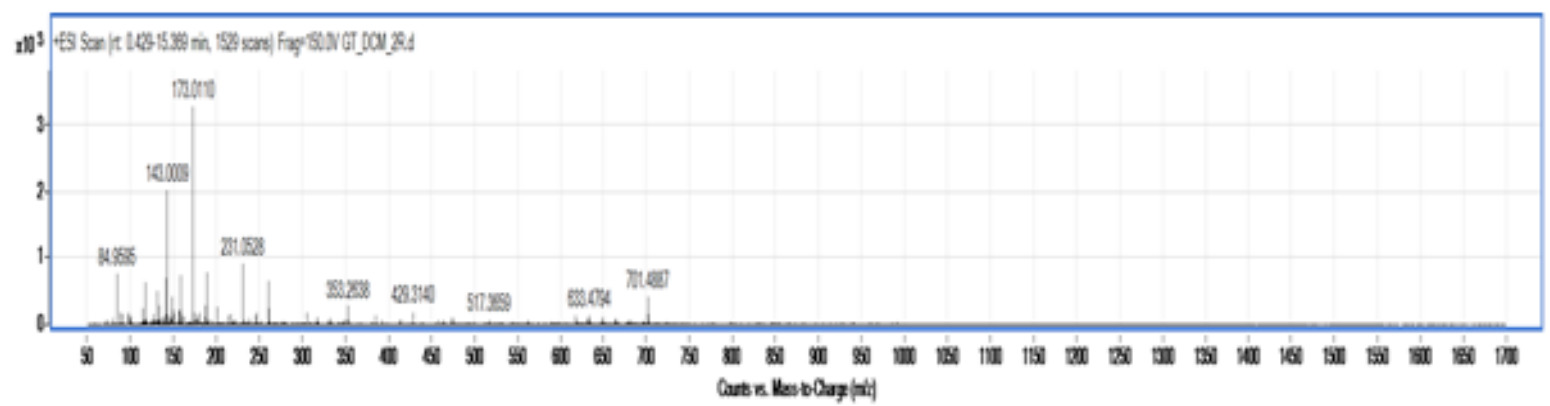

Figure4. Mass spectrum of G. tenax DCM extract 
Table1. DCM extraction of A. pannosum leaves sample

\begin{tabular}{|c|c|c|c|c|c|c|c|c|}
\hline Sr & Name & M.F & RT & $\begin{array}{l}\% \text { of } \\
\text { Conc }\end{array}$ & $\begin{array}{l}\text { Mtln } \\
\text { ID }\end{array}$ & Note & Structure & Ref. \\
\hline 1 & (-)-Sedamine & $\begin{array}{c}\mathrm{C}_{14} \\
\mathrm{H}_{21} \mathrm{~N} \\
\mathrm{O}\end{array}$ & 11.081 & 14.78 & 64453 & Alkaloids & & 12,22 \\
\hline 2 & $\begin{array}{c}(22 E)- \\
26,26,26,27,27,27- \\
\text { hexafluoro-25- } \\
\text { hydroxy-22,23- } \\
\text { didehydrovitamin } \\
\text { D3 }\end{array}$ & $\begin{array}{c}\mathbf{C}_{27} \\
\mathbf{H}_{36} \mathbf{F}_{6} \\
\mathbf{O}_{2}\end{array}$ & 12.109 & 20.41 & 42021 & Sterol Lipids & & 13 \\
\hline 3 & $\begin{array}{l}\text { N-Methyl-(R,S)- } \\
\text { tetrahydrobenzylis } \\
\text { oquinoline }\end{array}$ & $\begin{array}{c}\mathbf{C}_{17} \\
\mathrm{H}_{19} \mathrm{~N}\end{array}$ & 11.148 & 12.27 & 66304 & Alkaloids & & 14 \\
\hline 4 & $\begin{array}{c}\text { 8E-Tetradecenyl } \\
\text { acetate }\end{array}$ & $\begin{array}{l}\mathbf{C}_{16} \\
\mathbf{H}_{30} \\
\mathbf{O}_{2}\end{array}$ & 11.84 & 9.68 & 46290 & Not reported & & 15 \\
\hline 5 & $\begin{array}{c}\text { 1-(9Z- } \\
\text { nonadecenoyl)- } \\
\text { glycero-3-phospho- } \\
\text { (1'-myo-inositol) }\end{array}$ & $\begin{array}{c}\mathbf{C}_{28} \\
\mathbf{H}_{53} \\
\mathbf{O}_{12} \mathbf{P}\end{array}$ & 11.101 & 5.67 & 81183 & $\begin{array}{l}\text { Glycerophosp } \\
\text { holipids }\end{array}$ & & 16 \\
\hline 6 & $\begin{array}{c}\text { Furfural diethyl } \\
\text { acetyl }\end{array}$ & $\begin{array}{c}\mathrm{C}_{9} \mathrm{H}_{14} \\
\mathrm{O}_{3}\end{array}$ & 10.882 & 4.11 & 69937 & $\begin{array}{l}\text { Heterocyclics } \\
\text { compounds } \\
\text { (Uses as flavor } \\
\text { additive and } \\
\text { biofuel liquid) }\end{array}$ & & 17 \\
\hline 7 & $\begin{array}{c}\text { 3'-N-Acetyl-4'-O- } \\
\text { (9- } \\
\text { octadecenoyl)fusar } \\
\text { ochromanone }\end{array}$ & $\begin{array}{c}\mathbf{C}_{35} \\
\mathbf{H}_{54} \mathbf{N}_{2} \\
\mathbf{O}_{6}\end{array}$ & 11.664 & 13.13 & 93238 & Fatty Acid & & 18 \\
\hline 8 & $\begin{array}{l}\text { Yamogenin 3-O- } \\
\text { neohesperidoside }\end{array}$ & $\begin{array}{l}\mathrm{C}_{39} \\
\mathrm{H}_{62} \\
\mathrm{O}_{12}\end{array}$ & 12.218 & 2.16 & 67269 & $\begin{array}{c}\text { Steroid } \\
\text { Glycoside } \\
\text { (sapogenins) }\end{array}$ & & 19 \\
\hline 9 & Trolox & $\begin{array}{l}\mathrm{C}_{14} \\
\mathrm{H}_{18} \\
\mathrm{O}_{4}\end{array}$ & 11.174 & 2.62 & 45333 & Antioxidant & & 20,44 \\
\hline 10 & $\begin{array}{c}\text { (6R)-vitamin D2 } \\
\text { 6,19-sulfur dioxide } \\
\text { adduct }\end{array}$ & $\begin{array}{l}\mathrm{C}_{28} \\
\mathrm{H}_{44} \\
\mathrm{O}_{3} \mathrm{~S}\end{array}$ & 11.218 & 15.16 & 41911 & Sterol Lipids & & 19 \\
\hline
\end{tabular}


Table2. DCM extraction of G. tenax leaves sample

\begin{tabular}{|c|c|c|c|c|c|c|c|c|}
\hline Sr & Name & M.F & RT & $\begin{array}{l}\text { \% of } \\
\text { Conc }\end{array}$ & $\begin{array}{l}\text { Mtln } \\
\text { ID }\end{array}$ & Note & Structure & Ref \\
\hline 1 & $\begin{array}{c}1- \\
\text { Monopalmitin }\end{array}$ & $\begin{array}{c}\mathrm{C}_{19} \\
\mathrm{H}_{38} \mathrm{O}_{4}\end{array}$ & 12.908 & 4.09 & 24076 & $\begin{array}{l}\text { Intermediat } \\
\text { es and } \\
\text { microwave } \\
\text { reactor }\end{array}$ & & 21 \\
\hline 2 & (-)-Sedamine & $\begin{array}{c}\mathrm{C}_{14} \\
\mathrm{H}_{21} \mathrm{~N} \\
\mathrm{O}\end{array}$ & 11.081 & 2.26 & 64453 & Alkaloids & & 12,22 \\
\hline 3 & $\begin{array}{l}\text { 14,14,14- } \\
\text { Trifluoro-11E- } \\
\text { tetradecenyl } \\
\text { acetate }\end{array}$ & $\begin{array}{c}\mathbf{C}_{16} \\
\mathrm{H}_{27} \mathrm{~F}_{3} \\
\mathrm{O}_{2}\end{array}$ & 11.51 & 12.71 & 46326 & Fatty Ester & & 23 \\
\hline 4 & Cycasin & $\begin{array}{l}\mathbf{C}_{8} \mathbf{H}_{16} \\
\mathbf{N}_{2} \mathbf{O}_{7}\end{array}$ & 10.902 & 1.54 & 65593 & $\begin{array}{l}\text { Carcinogen } \\
\text { ic, Toxic } \\
\text { glycoside }\end{array}$ & & 24 \\
\hline 5 & $\begin{array}{c}\text { 8E- } \\
\text { Tetradecenyl } \\
\text { acetate }\end{array}$ & $\begin{array}{c}\mathrm{C}_{16} \\
\mathrm{H}_{30} \mathrm{O}_{2}\end{array}$ & 11.836 & 6.67 & 46290 & $\begin{array}{l}\text { No activity } \\
\text { reported }\end{array}$ & & 15 \\
\hline 6 & $\begin{array}{c}\mathrm{N}- \\
\text { Carbamylgluta } \\
\text { mate }\end{array}$ & $\begin{array}{l}\mathbf{C}_{6} \mathrm{H}_{10} \\
\mathbf{N}_{2} \mathbf{O}_{5}\end{array}$ & 10.825 & 0.77 & 44787 & $\begin{array}{c}\text { Enzyme, } \\
\text { protein synt } \\
\text { hase, } \\
\text { enhanced } \\
\text { growth } \\
\text { performanc } \\
\text { e and } \\
\text { improved } \\
\text { intestinal } \\
\text { function in } \\
\text { weaned } \\
\text { piglets }\end{array}$ & & 25 \\
\hline 7 & $\begin{array}{c}\text { Termitomycam } \\
\text { ide B }\end{array}$ & $\begin{array}{c}\mathbf{C}_{28} \\
\mathbf{H}_{40} \mathbf{N}_{2} \\
\mathbf{O}_{2}\end{array}$ & 11.583 & 1.32 & 96488 & $\begin{array}{l}\text { Fatty acid, } \\
\text { Reduce } \\
\text { oxidative } \\
\text { stress in } \\
\text { Endoplasmi } \\
\text { c reticulum } \\
\text { (ER) }\end{array}$ & & 26,27 \\
\hline 8 & $\begin{array}{c}\text { Deterrol } \\
\text { stearate }\end{array}$ & $\begin{array}{c}\mathbf{C}_{33} \\
\mathbf{H}_{50} \mathrm{O}_{2}\end{array}$ & 11.826 & 4.83 & 90042 & $\begin{array}{l}\text { Sesquiterpe } \\
\text { nes }\end{array}$ & & 28 \\
\hline 9 & $\begin{array}{l}\text { Panaxydol } \\
\text { linoleate }\end{array}$ & $\begin{array}{c}\mathrm{C}_{35} \mathbf{H}_{54} \\
\mathrm{O}_{3}\end{array}$ & 11.821 & 5.06 & 95626 & $\begin{array}{l}\text { Nutrient, } \\
\text { Stabilizers, } \\
\text { Surfactants } \\
\text { and } \\
\text { Emulsifiers, } \\
\text { used in } \\
\text { cosmetics }\end{array}$ & & 29 \\
\hline 10 & $\begin{array}{c}\text { Red } \\
\text { chlorophyll } \\
\text { catabolite }\end{array}$ & $\begin{array}{c}\mathbf{C}_{35} \\
\mathbf{H}_{38} \mathbf{N}_{4} \\
\mathbf{O}_{7}\end{array}$ & 11.826 & 0.87 & 63971 & Protein & & 30 \\
\hline
\end{tabular}




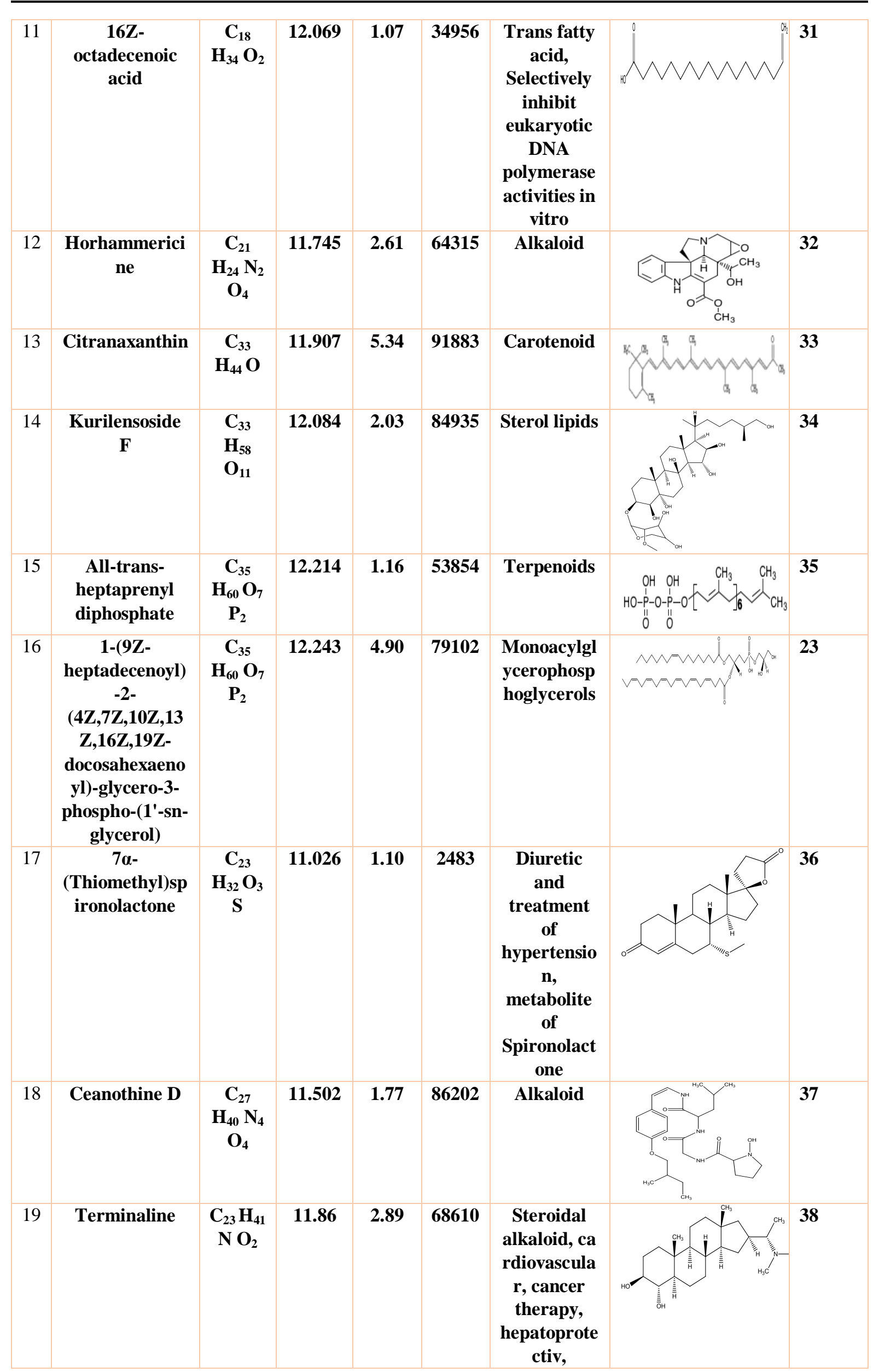




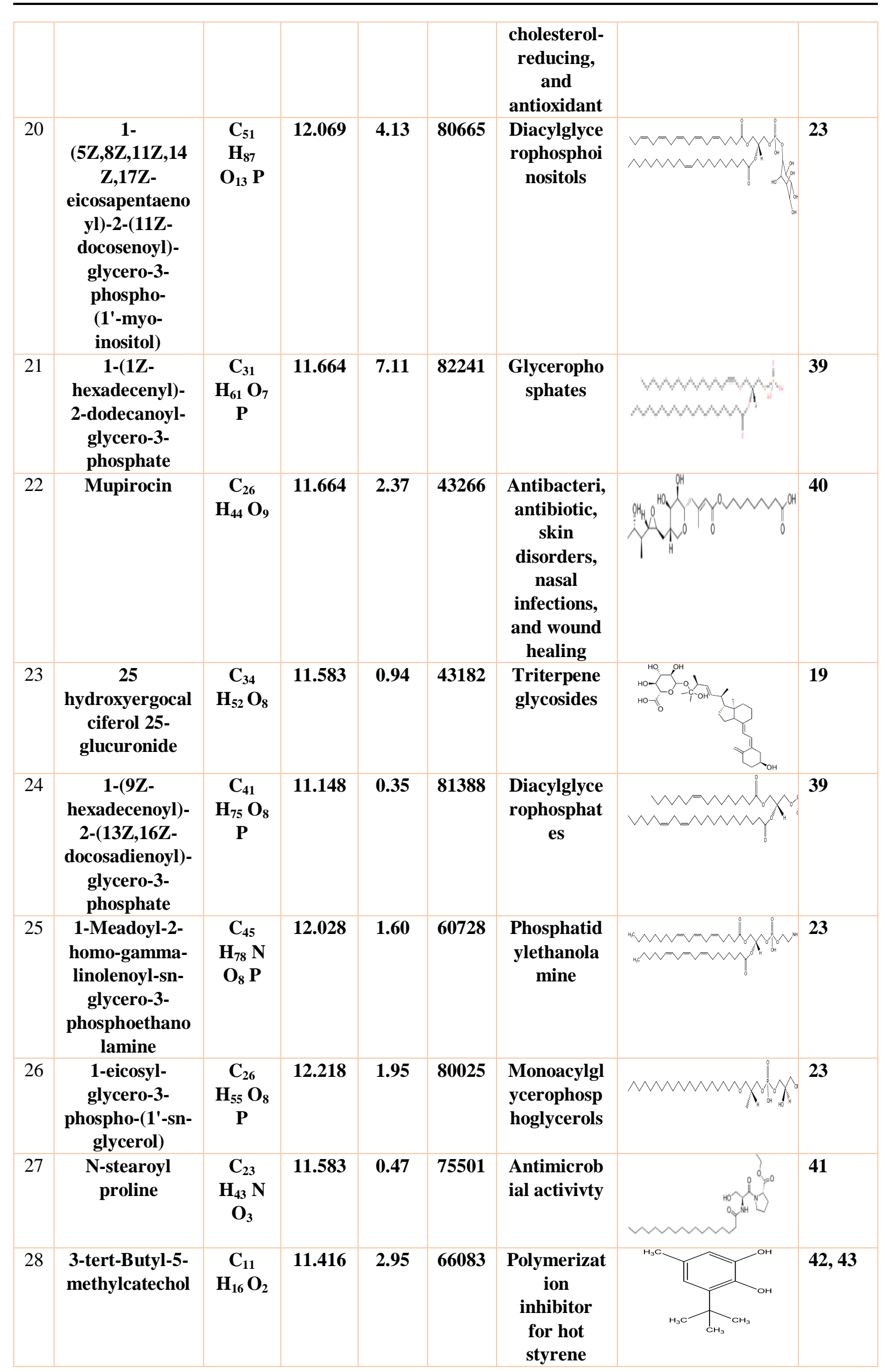




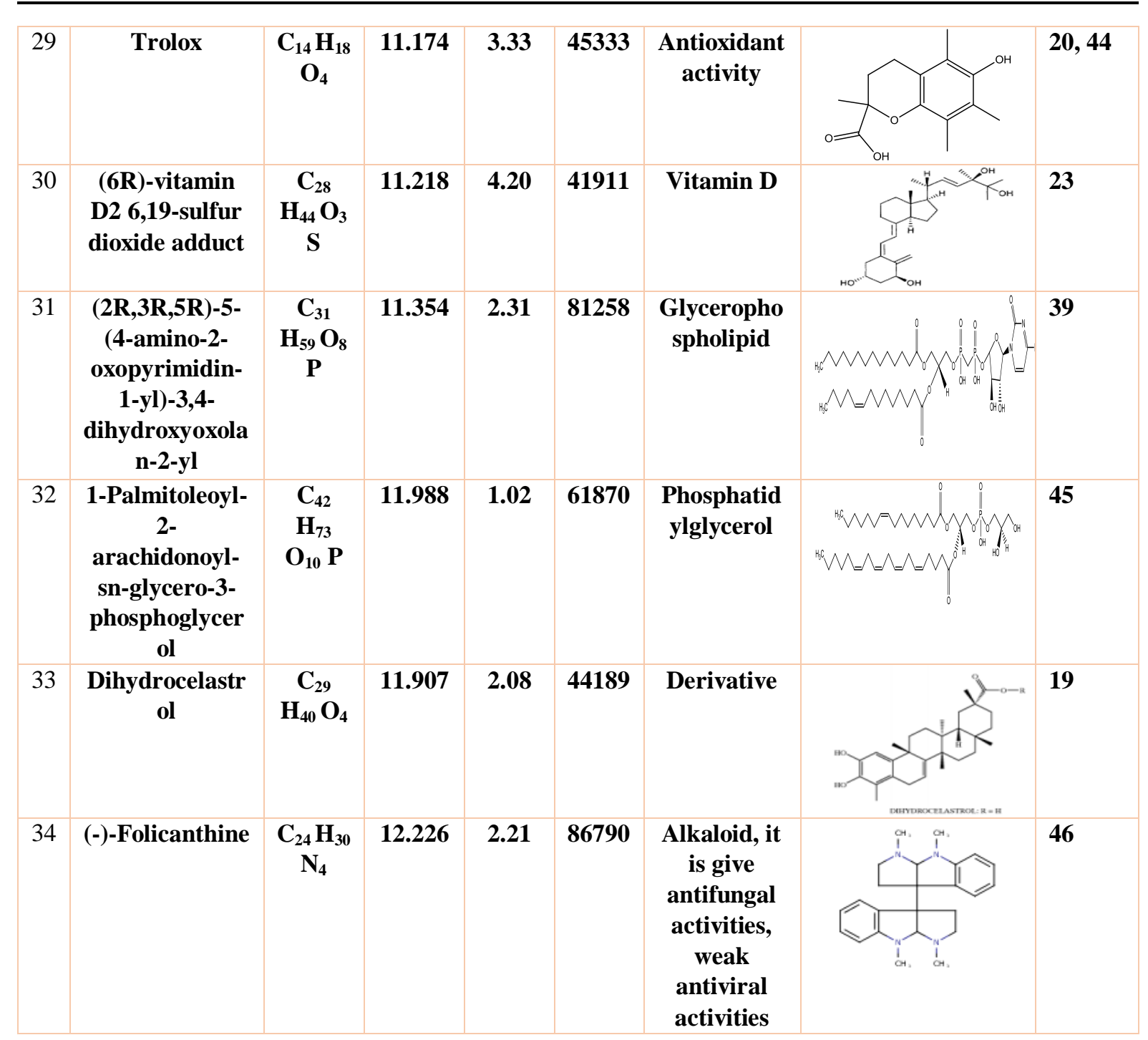

\section{1.pannosum DCM extract}

Table 1 represents DCM extract of A. pannosum gives alkaloids, sterol lipids, glycerophospholipids, fatty acid, steroid glycoside, antioxidant, and heterocyclic compounds.

According to above results showed that total ten type bioactive compound present in DCM extract of A. pannosum. It was mainly found to be in order of (22E)-26,26,26,27,27,27-hexafluoro-25-hydroxy22,23-didehydrovitamin D3 (20.41\%), (6R)-vitamin D2 6,19-sulfur dioxide adduct (15.16\%), (-)Sedamine (14.78\%), 3'-N-Acetyl-4'-O-(9-octadecenoyl) fusarochromanone (13.13\%), N-Methyl(R,S)-tetrahydrobenzylisoquinoline(12.27\%),1-(9Z-nonadecenoyl)-glycero-3-phospho-(1'-myoinositol) (5.67\%), Furfural diethyl acetal (4.11\%), Trolox (2.62\%) and Yamogenin 3-O-neohesperidoside $(2.16 \%)$.

\section{2.tenax DCM extract}

Table2 represents DCM extract of $G$. tenax leaves gives alkaloids, sterol lipids, glycerophospholipids, fatty ester, fatty acid, glycoside, carotene, steroidal alkaloid, triterpene glycosides, glycerolphosphates, sesquiterpenes, phosphatidylglycerol, antioxidant, antibacterial, antifungal, antiviral activity and other biological function.

According to above results showed that total 34 type bioactive compound present in DCM extract of G. tenax. It was mainly found to be in order of 14,14,14-Trifluoro-11E-tetradecenyl acetate $(12.71 \%)$, Citranaxanthin (5.34\%), Panaxydol linoleate (5.06\%), Deterrol stearate (4.83\%), 1-Monopalmitin (4.09\%), Trolox (3.33\%), 3-tert-Butyl-5-methylcatechol (2.95\%), Terminaline (2.89\%), Horhammericine (2.61\%), Mupirocin (2.37\%), (-)-Sedamine (2.26\%), (-)-Folicanthine (2.21\%), Kurilensoside F (2.03\%), Ceanothine D (1.77\%), Termitomycamide B (1.32\%), All-trans-heptaprenyl diphosphate 
(1.16\%),7 $\alpha$-(Thiomethyl)spironolactone (1.10\%), 16Z-octadecenoic acid (1.07\%), 25 hydroxyergocalciferol 25-glucuronide $(0.94 \%)$, Red chlorophyll catabolite $(0.87 \%)$, N-Carbamylglutamate $(0.77 \%)$ and $\mathrm{N}$-stearoyl proline $(0.47 \%)$.

\section{DISCUSSION}

A variety of herbs and herbal extracts contain different phytochemicals with biological activity that can be of valuable therapeutic index. Much of the protective effect of herbal plants has been attributed by phytochemicals, which are the non-nutrient compounds. ${ }^{[47]}$ Different phytochemicals have been found to possess a wide range of activities, which may help in safety against sustained diseases. ${ }^{[48]}$ The phytochemical investigation of the leaves of A. pannosum (A.P) and G. tenax (G.T) showed that the leaves contain most of the secondary metabolites analysed. They were revealed to possess sterol lipids, alkaloids, phenolic compounds, sterol glycosides, triterpene glycoside, steroids, carotenoid, tannins, fatty acids and triterpenoids. Phytosterols are the sterols of plant origin, which have been shown to possess cholesterol lowering ${ }^{[49]}$ as well as anticancer property. ${ }^{[50]}$

According to the result two sterol lipids i.e.,(22E)-26, 26, 26, 27, 27, 27-hexafluoro-25-hydroxy-22, 23-didehydrovitamin D3 and (6R)-vitamin D2 6,19-sulfur dioxide adduct were shown in A.P and nine sterol lipids i.e.,(2R,3R,5R)-5-(4-amino-2-oxopyrimidin-1-yl)-3,4-dihydroxyoxolan-2-yl,1-Palmitoleoyl-2-arachidonoyl-sn-glycero-3-phosphoglycerol,1-eicosyl-glycero-3-phospho-(1'-sn-glycerol),1-(1 Z-hexadecenyl)-2-dodecanoyl-glycero-3-phosphate,1-Meadoyl-2-homo-gammalinol-enoylsnglycero3 phosphoethanolamine,1-(9Z-hexadecenoyl)-2-(13Z,16Zdocosadienoyl)-glycero-3phos-phate, 1(5Z,8Z, 11Z,14Z,17Z-eicosapentaenoyl)-2-(11Z-docosenoyl)-glycero-3-phospho-(1'-myo-inositol),1-(9Zhepta decenoyl)-2-(4Z,7Z,10Z,13Z,16Z,19Z-docosahexaenoyl)-glycero-3-pho-sphor-(1'-snglycerol)and Kurilensoside $\mathrm{F}$ were shown in G.T.Sterol lipids are major components of biological membranes.It is present in smaller amounts act as enzyme cofactors, electron carriers and light absorbing pigments, hydrophobic anchors for proteins, emulsifying agents, hormones and intracellular messengers.[51] Here,1-Palmitoleoyl-2-arachidonoyl-sn-glycero-3-phosphoglycerol(i.e.,phosphatidylglycerols) exhibit important role as a precursor for the synthesis of cardiolipin.[52]

Yamogenin 3-O-neohesperidoside was shown only in A.P. It is sterol glycoside. Sterol glycosides have also been added to dietary supplements designed to improve lipid metabolism and immune function. ${ }^{[53]}$ New findings within the past five years have discovered these compounds to be involved in complex cell-signal transduction mechanisms, resulting in selective control of human tumors but not normal cellular proliferation and they represent a promising form of targeted cancer chemotherapy. ${ }^{[54]}$

14,14,14-Trifluoro-11E-tetradecenyl acetate $(12.71 \%)$ and Citranaxanthin are carotenoid, which are existing in G.T. Carotenoids may act as antioxidants and may exhibit chemo preventive anti atherosclerotic effects and anticancer effects ${ }^{[55]}$ carotenoid pigments primarily plays role in the production of vitamin-A. It is support the maintenance of healthy epithelial cell differentiation, normal reproductive performance, and visual functions. ${ }^{[6-57]}$ additionally, carotenoids also play an important role in human health as protecting cells and tissues from the oxidative damaging effects of free radicals and singlet oxygen. ${ }^{[58-59]}$ Many studies show strong correlations between carotenoids intake and a reduced risk of some diseases, such as cancer, ${ }^{[60-61]}$ atherogenesis, ${ }^{\left[{ }^{[2-63]}\right.}$ bone calcification, ${ }^{[64]}$ eye degeneration, ${ }^{[65-66]}$ immune function ${ }^{[67-68]}$ and neuronal damage. ${ }^{[69]}$

The human body needs essential fatty acids to construct and repair cell membranes enabling the cells to obtain optimum nutrition and expel harmful waste products. ${ }^{[70]}$ A primary function of essential fatty acids, which support the cardiovascular, reproductive, immune and nervous systems, is the production of prostaglandins. ${ }^{[71]}$ These regulate body functions such as heart rate, blood pressure, blood clotting, fertility and play a role in immune system by regulating inflammation. ${ }^{[72-74]}$ In A.P present one fatty acid component which is 3'-N-Acetyl-4'-O-(9-octadecenoyl) fusarochromanone and G.T showed two fatty acid component i.e., termitomycamide B, and 16Z-octadecenoic acid are fatty acid.

Alkaloids that are responsible for the therapeutic effect of many medicinal plants. Earlier studies have indicated that alkaloids possess antihyperglycemic and antilipidemic effects suggesting their beneficial effect in the management of diabetes associated with abnormal lipid profile and related 
cardiovascular diseases. ${ }^{[75]}$ Alkaloids are used in medicines for reducing headache and fever. These are ascribed for antibacterial and analgesic properties. ${ }^{\left[{ }^{[6]}\right.}$ Some alkaloids are present in both plant i.e, (-)-Sedamine and N-Methyl-(R,S)-tetrahydrobenzylisoquinoline. When Horhammericine Ceanothine D, Terminaline and (-)-Folicanthine are present in G.T leaves sample. Terminaline act as a steroidal alkaloid, it is used in cardiovascular, cancer therapy, hepatoprotectiv, cholesterol-reducing, and also give antioxidant activity ${ }^{[38]}$ and (-)-Folicanthine is also provide antifungal activities, weak antiviral activities. ${ }^{[46]}$

All-trans-heptaprenyl diphosphate act as a terpenoids which was shown in G.T. Terpenoids exhibit various important pharmacological activities i.e., anti-inflammatory, anticancer, anti-malarial, inhibition of cholesterol synthesis, anti-viral and anti-bacterial activities. ${ }^{[77]}$ Terpenoids are very important in enticing valuable mites and consume the herbivorous insects. ${ }^{[78]}$ Furfural diethyl acetyl present in A.P. It is one type of heterocyclic compounds which is uses as flavour additive and biofuel liquid. ${ }^{[17]}$ Trolox were existing in both plant leaves sample. Trolox is antioxidant agent thus, it is used in biological or biochemical applications to reduce oxidative stress or damage. ${ }^{[20,44]} 7 \alpha$-(Thiomethyl) spironolactone is heterocyclic compound i.e., present in G.T. It is use for convenient in diuretic, treatment of hypertension and metabolite of Spironolactone. ${ }^{[36]}$

G.T contained 25 hydroxyergocalciferol 25-glucuronide i.e., triterpene glycosides. Triterpene glycosides are well-known for their cytotoxic, antimicrobial, anticoagulant, hemolytic, antiviral, antiparasitic and antitumor properties. Some glycosides can prevent the growth ${ }^{[79]}$ survival, invasion ${ }^{[80,81]}$ and metastasis ${ }^{[82]}$ of cancerous cells; others possess immunomodulatory activity, ${ }^{[83]}$ or inhibit the sodium-potassium ATPase, ${ }^{[84]}$ and even elicit apoptosis ${ }^{[85]}$ G.T also have red chlorophyll catabolite i.e., one type of protein molecule ${ }^{[30]}$ and $\mathrm{N}$-carbamylglutamate, mupirocin and $\mathrm{N}$-stearoyl proline are compound which have antimicrobial activity. ${ }^{[25,40,41]}$ Mupirocin is also useful as an antibiotic, skin disorders, nasal infections, and wound healing. ${ }^{[40]}$

\section{CONCLUSION}

The present study was conducted on DCM extracts of A. pannosum and G. tenax evaluated in this work has different varieties of phytochemicals i.e., sterol lipids, alkaloids, phenolic compounds, sterol glycosides, triterpene glycoside, steroids, carotenoid, tannins, fatty acids and triterpenoids, that could be considered as responsible for medicinal activities. According to the above result exhibited in table $1 \& 2$, we have found that both plant showed different types of phytochemicals. The presence of $G$. tenax give good medicinal activity compared to the A. pannosum, since of G.T has contain higher amount of phytochemicals except sterol glycoside. This study also leads to the further research in the way of isolation and identification of the active compound from the selected fern using chromatographic and spectroscopic techniques. According to the literature search, there is no work that has been done on analysis of DCM extracts of A. pannosum and G. tenax by the researcher.

\section{ACKNOWLEDGEMENT}

We would like to thank the KSKV Kachchh University (Bhuj), Department of Chemistry to permit for this work. We would also thank to Junagadh Agriculture Food Testing Laboratory for providing facility for this work and guidance.

\section{REFERENCES}

[1] Fennell, C.W.; Lindsey, K.L., McGaw, L.J., Sparg, S.G., Stafford, G.I., Elgorashi, E.E., Grace, O.M. \& van Staden; Assessing African medicinal plants for efficacy and safety: pharmacological screening and toxicology; Journal of Ethnopharmacoly, (2004); 94: 205-217.

[2] Verpoorte, R., Chemodiversity and the Biological Role of Secondary metabolites, some thoughts for selecting plant material for drug development; Proc. Phytochem. Soc. Europe, Kluwer Publishers, (1998); 43(4): 11-24.

[3] Sandhya, B., Thomas, S., Isabel, W. and Shenbagarathai, R.; Ethnomedicinal Plants Used by the Valaiyan Community of Piranmalai Hills (Reserved Forest), Tamil Nadu, India. A Pilot Study; The African Journal of Traditional, Complementary and Alternative Medicines, (2006); 3: 101-114.

[4] Akindele A. J. and Adeyemi O. O.; Antiinflammatory activity of the aqueous leaf extract of Byrsocarpus coccineus; Fitoterapia, (2007); 78: 25-28.

[5] Abedin S. ;Abutilon muticum and Abutilon pannosum complex; Pak. J. Bot. (1980); 12(1):43-48. 
[6] Sammia Y. ; Studies on bioactive natural products of selected species of family Malvaceae; Ph. D Thesis, Department of Chemistry GC University, Lahore, (2008)

[7] FAO. Traditional Food Plants: A Resource Book for Promoting the Exploitation Consumption of Food Plant in Arid, Semi-arid and Sub-humid Lands of Eastern Africa; Rome: FAO Food and nutrition paper; (1988), 42.

[8] B. Dod, (Ed.); Flowering Plants of the World; Oxford University Press, London; (1978), 90-91.

[9] Elmuez Alsir. A. Aboagarib, Ruijin Yang, Xia Hua, Azhari Siddeeg; Chemical Compositions, Nutritional Properties and Volatile Compounds of Guddaim (Grewia Tenax. Forssk) Fiori Fruits; Journal of Food and Nutrition Research. (2014); 2(4):187-192.

[10] Morris H R, Paxton T, Dell A, Langhorne J, Berg M, Bordoli RS, Hoyes J, Bateman R H;High sensitivity collisionally-activated decomposition tandem mass spectrometry on a novel quadrupole/orthogonalacceleration time-of-flight mass spectrometer; Rapid Commun Mass Spectrom. (1996); 10, 889.

[11] Shevchenko AA, Chernushevich IV, Ens W, Standing KG, Thomson B, Wilm M, Mann M. "Rapid 'de novo' peptide sequencing by a combination of nanoelectrospray, isotopic labeling and a quadrupole/timeof-flight mass spectrometer; Rapid Commun Mass Spectrom. (1997); 11: 1015-24.

[12] François-Xavier Felpin and Jacques Lebreton; A Highly Stereoselective Asymmetric Synthesis of (-)Lobeline and (-)-Sedamine; J. Org. Chem. (2002), 67 (26), 9192-9199.

[13] http://www.lipidmaps.org

[14] http://www.ebi.ac.uk

[15] http://www.chemspider.com

[16] http://www.lipidmaps.org

[17] Mikhail Yu, Chernyak, Valery E, Tarabanko, Andrey A. Morosova and Alexander A. Kondrasenkoa; Preparative Synthesis of Furfural Diethyl Acetal through the Direct Interaction of the Alcohol and Aldehyde; Journal of Siberian Federal University Chemistry (Nov. 2016); 2, 146-151.

[18] Weiping Xie, Chester J. Mirocha, Yechun Wen, Won Jo Cheong, Robert J. Pawlosky; Isolation and structure elucidation of four fatty acid derivatives of the mycotoxin fusarochromanone produced by Fusarium equiseti; J. Agric. Food Chem.(1991); 39: 1757-1761.

[19] https://pubchem.ncbi.nlm.nih.gov

[20] Dejian Huang, Boxin Ou and Ronald L. Prior; The Chemistry behind Antioxidant Capacity Assays; $J$. Agric. Food Chem. (2005); 53 (6): 1841-1856.

[21] Dani, J. A. ;Overview of nicotinic receptors and their roles in the central nervous system; Biol. Psychiatry, (2001); 49, 166-174.

[22] El Ghazali GEB, El Tohami MS, El Egami AAB; Medicinal plants of the Sudan. In: Medicinal plants of the White Nile provinces" Khartoum University Press, Khartoum; (1994).

[23] www.lipidmaps.org

[24] G. L. Laqueur and M. Spatz;Toxicology of Cycasin National Institute of Arthritis and Metabolic Diseases, NJH, Bethesda, Maryland 20014, Cancer research (Nov. 1968); 28, 2262-2267.

[25] Yang H. S., Fu D. Z., Kong X. F., Wang W. C., Yang X. J., Nyachoti C. M., and Yinf, Y. L.;Dietary supplementation with $\mathrm{N}$-carbamylglutamate increases the expression of intestinal amino acid transporters in weaned Huanjiang mini-pig piglets; J. Anim. Sci., (2013); 91:2740-2748

[26] Choi J.H, Maeda K, Nagai K, Harada E., Kawade M., Hirai H., and Kawagishi H., Termitomycamides A to E, Fatty Acid Amides Isolated from the Mushroom Termitomyces titanicus, Suppress Endoplasmic Reticulum Stress; Organic letters. (2010); 12: 5012-5015.

[27] Enjalbert F, Gallion C, Jehl F, Monteil H \& Faulstich H; Simultaneous assay for amatoxins and phallotoxins in Amanita phalloides Fr. by high-performance liquid chromatography; Journal of Chromatography, (1992); 598: 227-236.

[28] Kirtikar KR, Bashu BD; Indian Medicinal Plants” International Book Distributors, Dehradun, (1998); 1, 1045- 1048 .

[29] Kitts D D and Hu C.;Efficacy and safety of ginseng” Public Health Nutrition. (2000); 3: (4A): 473-485.

[30] Buchanan, B.B.; Role of Light in the Regulation of Chloroplast Enzymes; Annul Rev. Plant Physiol. (1980); 31, 341-374.

[31] Thurnhofer, S.; Vetter, W. ; A gas chromatography/electron ionization-mass spectrometry-selected ion monitoring method for determining the fatty acid pattern in food after formation of fatty acid methyl esters; J. Agric. Food Chem. (2005); 53: 8896-8903.

[32] http://www.genome.jp 
[33] El-Qudah J M. ; Dietary Intake of Selected Common Vegetable Foods and their Total Carotenoids Determination; Am. J. Agric. Biol. Sci., (2008); 3(4): 729-733.

[34] Stonik, V.A.; Marine polar steroids; Usp. Khim., 2001, vol. 70, pp. 673-715

[35] Hemming, F. W. in MTP International Review of science, Biochemistry Series I (Goodwin, T. W., ed), Buttenvorths, London, (1974); 4, 39-97.

[36] Rettie AE, Fisher MB. ;Transformation enzymes: Oxidative; Non-P450. In Woolf TF editor; Handbook of Drug Metabolism. New York: Marcel Dekker Inc., (1999), 142-151.

[37] K. Kummerer; Pharmaceuticals in the Environment - A Brief Summary, Pharmaceuticals in the Environment, $3^{\text {rd }}$ Edition: Springer Berlin Heidelberg, (2008); 3-21.

[38] Bath, R. B., Jacobs, T. W., Traditional herbal medicine in Transkei; Journal of Ethnopharmacology, (1995); 48: 7-12.

[39] Rodríguez-Alcalá, L.M.; Calvo, M.V.; Villar-Tajadura, M.A.; Castro-Gómez, M.d.P.; Holgado, F.; Juárez, M.; Fontecha, J. "Lípidos bioactivos en productos lácteos" In Avances en la Investigación de la Alimentación Funcional; Fontecha, J., Ed.; Programa CYTED: Madrid, Spain, (2010).

[40] Eltringham I. ;Mupirocin resistance Staphylococcus and methicillin-resistant aureus; J Hosp Infect, (1997); 3, 1-8.

[41] www.researchgate.net

[42] www.chemsrc.com

[43] www.freepatentsonline.com

[44] http://www.sigmaaldrich.com

[45] www.ebi.ac.uk

[46] http://www.hmdb.ca

[47] Gurib-Fakim; Medicinal plants: Traditions of yesterday and drugs of tomorrow; Review article. Mol. Aspects Med. (2006); 27 (1):1-93.

[48] Newman, D.J.; Cragg, G.M. "In Drug Discovery, Therapeutics, and Preventive Medicine" Zhang, L., Fleming, A., Demain, A.L., Eds.; Humana Press: Totowa, NJ, USA, (2005); 74.

[49] Jong, D. Plat, J. and Mensink, R.P., Metabolic effects of plant sterols and stanols (Review), J, Nutr Biochem, (2003); 14(7): 362-369.

[50] Von, H.R.L., Fink, C.S. and Awad, A.B. $\beta$-Sitosterol activates the sphingomyelin cycle and induces apoptosis in LNCaP human prostate cancer cells, Nutr Cancer, (1998); 32: 8-12.

[51] Berg, J.M., Tymoczko, J.L. and Stryer, L. "Biochemistry (6 ${ }^{\text {th }}$ Edition)" (2007); W.H. Freeman and Co., New York. ISBN 0-7167-8724-5.

[52] Mathews, C.K., van Holde, K.E. and Ahern, KG. "Biochemistry" (3 ${ }^{\text {rd }}$ Edition), Pearson Education Inc.; 2003, ISBN 91-297-0215-0.

[53] Bouic, P.J., Clark, A., Lamprecht, J., Freestone, M., Pool, E.J., Liebenberg, R.W., Kotze, D.V. and Jaarsveld, P.P.; The effects of $\beta$-sitosterol (BSS) and $\beta$-sitosteryl glucoside (BSSG) mixture on selected immune parameters of marathon runners: Inhibition of post marathon immune suppression and inflammation; Int. J. Sports Med., (1999); 20: 258-262.

[54] Sharma,V., Singh, M.,Isolation and Characterization of Stigma-5,22dien-3-O- $\beta$-D-Glucopyranoside from the ethanolic root extract of Operculina turpethum; International Journal of Advanced Research (2013); 1(8), 303-312

[55] Salah, N., Miler, N. J., Pagange G, Tijburg, L., Bolwell G. P., Rice, E., et al. ,Polyphenolic flavonoids as scavenger of aqueous phase radicals as chain breaking antioxidant, Arch Biochem Broph (1995); 2: 33946.

[56] Combs, G. F., "Vitamin A in the vitamins: Fundamental Aspects in Nutrition and Health." $2^{\text {nd }}$ ed. San Diego: Academic Press, (1995); 107-153.

[57] Miki W. "Biological functions and activities of animal carotenoids." Appl Chem (1991); 63(1):141-146.

[58] Nishino H, Murakoshi M, Ii T, Takemura M, Kuchide M, Kanazawa M, Mou XY, Wada S, Masuda M, Ohsaka Y, Yogosawa S, Satomi Y, Jinno K. ; Carotenoids in cancer chemoprevention; Cancer Metastasis Rev, (2002); 21:257-4.

[59] Lian F, Hu K.Q, Russell R.M, Wang X.D. ; $\beta$-Cryptoxanthin suppresses the growth of immortalized human bronchial epithelial cells and non-small-cell lung cancer cells and up-regulates retinoic acid receptor b expression; Int J Cancer, (2006); 119: 2084-2089. 
[60] Nishino H,; Prevention of hepatocellular carcinoma in chronic viral hepatitis patients with cirrhosis by carotenoid mixture; Recent Results Cancer Res, (2007); 174: 67-71.

[61] Lidebjer C, Leanderson P, Ernerudh J, Jonasson L. ;Low plasma levels of oxygenated carotenoids in patients with coronary artery disease; Nutr Metab Cardiovasc Dis (2007); 17: 448-56.

[62] Osganian SK, Stampfer MJ, Rimm E, Spiegelman D, Manson JE, Willett WC ;Dietary carotenoids and risk of coronary artery disease in women." Am J Clin Nutr (2003); 77: 1390-9.

[63] Yamaguchi M, Uchiyama S. "Effect of carotenoid on calcium content and alkaline phosphatase activity in rat femoral tissues in vitro: the unique anabolic effect of beta-cryptoxanthin" Biol Pharm Bull, (2003); 26: 1188-91.

[64] Semba RD, Dagnelie G. "Are lutein and zeaxanthin conditionally essential nutrients for eye health?" Med Hypotheses, (2003); 61:465-72.

[65] Schalch W, Cohn W, Barker F.M. Köpcke W, Mellerio J, Bird A.C, Robson A.G, Fitzke F.F. van Kuijk F.J.G.M., "Xanthophyll accumulation in the human retina during supplementation with lutein or zeaxanthin - the LUXEA ( LUtein Xanthophyll Eye Accumulation ) study," Arch Biochem Biophys, (2007); 458:128-135.

[66] Sato Y, Akiyama H, Suganuma H, Watanabe T., Nagaoka MH, Inakuma T, Goda Y, Maitani T. "The feeding of beta-carotene down-regulates serum IgE levels and inhibits the type I allergic response in mice." Biol Pharm Bull, (2004); 27:978-84.

[67] Hughes DA, "Dietary carotenoids and human immune function.” Nutrition, (2001); 17: 823-7

[68] Okai Y, Higashi-Okai K, "Possible immunomodulating activities of carotenoids in in vitro cell culture experiments.” Int J Immunopharmocol, (1996); 18: 753-8.

[69] Stuerenburg H.J., Ganzer S., MullerThomsen T. "Plasma beta carotene in Alzheimer's disease. Association with cerebrospinal fluid beta-amyloid 1-40, (Abeta40), beta-amyloid 1-42 (Abeta42) and total Tau." Neuroendocrinol Lett, (2005); 26: 696-8.

[70] Connor WE “Importance of $\mathrm{n} 23$ fatty acids in health and disease.” Am J Clin Nutr, (2000), 71: 171.

[71] Tapiero, H., Ba, G.N., Couvreur, P., Tew, K.D., "Polyunsaturated fatty acids (PUFA) and eicosanoids in human health and pathologies" Biomed. Pharmacother, (2002); 56, 215-219.

[72] Torres-Duarte, A.P., Vanderhoek, J.Y., "Conjugated linoleic acid exhibits stimulatory and inhibitory effects on prostanoid production in human endothelial cells and platelets" Biochim. Biophys. Acta-Mol. Cell Res., (2003); 69, 1640-1647.

[73] Das, U., "Long-chain polyunsaturated fatty acids, endothelial lipase and atherosclerosis" Prostogl. Leukotr. Ess. Fatty Acids, (2005); 72, 173-179.

[74] Korotkova, M., Strandvik, B., "Essential fatty acid deficiency affects the fatty acid composition of the rat small intestinal and colonic mucosa differently" Biochim. Biophys. Acta-Mol.Cell Biol. Lipids, (2000); 319, 1487-1495.

[75] Balme F. "Plantas medicinais. Sao Paulo": Hemus Livraria, (1978); 398.

[76] Pietta PG, Flavonoids as antioxidants. J Nat Prod, (2000), 63: 1035-1042.

[77] Mahato SB, Sen S “Advances in triterpenoid research, 1990-1994.” Phytochemistry (1997); 44: 11851236.

[78] Kappers IF, Aharoni A, van Herpen TW, Luckerhoff LL, Dicke M, et al. "Genetic Engineering of Terpenoid Metabolism Attracts Bodyguards to Arabidopsis" Science (2005); 309: 2070-2072.

[79] Zhao, Q.; Xue, Y.; Liu, Z.D.; Li, H.; Wang, J.F.; Li, Z.J.; Wang, Y.M.; Dong, P.; Xue, C.H. "Differential effects of sulfated triterpene glycosides, holothurin A1, and 24-dehydroechinoside A, on antimetastasic activity via regulation of the MMP-9 signal pathway." J. Food Sci., (2010), 75, H280-H288.

[80] Al Marzouqi, N.; Iratni, R.; Nemmar, A.; Arafat, K.; Ahmed Al Sultan, M.; Yasin, J.; Collin, P.; Mester, J.; Adrian, T.E.; Attoub, S. ;Frondoside A inhibits human breast cancer cell survival, migration, invasion and the growth of breast tumor xenografts; Eur. J. Pharmacol. (2011), 668, 25-34.

[81] Ma, X.; Kundu, N.; Collin, P.D.; Goloubeva, O.; Fulton, A.M. Frondoside; A inhibits breast cancer metastasis and antagonizes prostaglandin E receptors EP4 and EP2.; Breast Cancer Res. Treat. (2012); 132: 1001-1008.

[82] Attoub, S.; Arafat, K.; Gélaude, A.; Al Sultan, M.A.; Bracke, M.; Collin, P.; Takahashi, T.; Adrian, T.E.; de Wever, O. ; Frondoside A suppressive effects on lung cancer survival, tumor growth, angiogenesis, invasion, and metastasis; PLOS ONE, (2013); 8: 1-10.

[83] Aminin, D.L.; Koy, C.; Dmitrenok, P.S.; Muller-Hilke, B.; Koczan, D.; Arbogast, B.; Silchenko, A.A.; Kalinin, V.I.; Avilov, S.A.; Stonik, V.A.; et al. "Immunomodulatory effects of holothurian triterpene glycosides on mammalian splenocytes determined by mass spectrometric proteome analysis; J. Proteom. (2009); 72: 886-906 
[84] Gorshkova, I.A.; Kalinin, V.I.; Gorshkov, B.A.; Stonik, V.A. "Two different modes of inhibition of the rat brain $\mathrm{Na}+, \mathrm{K}+$-ATPase by triterpene glycosides, psolusosides A and B from the holothurian Psolus fabricii; Comp. Biochem. Physiol. C Pharmacol. Toxicol. Endocrinol, (1999); 122: 101-108.

[85] Jin, J.O.; Shastina, V.V.; Shin, S.W.; Xu, Q.; Park, J.I.; Rasskazov, V.A.; Avilov, S.A.; Fedorov, S.N.; Stonik, V.A.; Kwak, J.Y. "Differential effects of triterpene glycosides, frondoside A and cucumarioside A2 -2 isolated from sea cucumbers on caspase activation and apoptosis of human leukemia cells." FEBS Lett. (2009); 583: 697-702.

Citation: M. Aadesariya et al., "Extraction, Isolation and Identification of Useful Phyto Constituents from Dichloromethane Leave Extract of Abutilon Pannosum and Grewia Tenax Using Q-TOF LC/MS", International Journal of Advanced Research in Chemical Science (IJARCS), vol. 4, no. 10, pp. 1-14, 2017. http://dx.doi.org/10.20431/2349-0403.0410001

Copyright: (C) 2017 Authors. This is an open-access article distributed under the terms of the Creative Commons Attribution License, which permits unrestricted use, distribution, and reproduction in any medium, provided the original author and source are credited. 